\title{
Perbandingan Struktur Modal Perusahaan Property Dan Kontruksi Bangunan Periode 2015-2019
}

\author{
Nialena yusniawati, Yuli Chomsatu, dan Suhendro \\ Program Studi Akuntansi, Universitas Islam Batik Surakarta, Surakarta, Indonesia \\ E-Mail : nialena0234@gmail.com
}

\begin{abstract}
Capital structure is a comparison of own capital with foreign capital owned by each company. Capital alone can be divided into retained earnings and company ownership. Meanwhile, foreign capital is short-term debt or long-term debt. The good and bad conditions of the company can be determined through the capital structure. Through the capital structure, the company can allocate funds owned for appropriate business activities as well as useful for the continuity of the company. In general, factors that affect the company's capital structure include profitability, liquidity, company size, sales growth, and asset structure. This study aims to find out the different influences of capital structures on property companies and building construction. This research uses property and building construction companies listed on the Indonesia Stock Exchange in 2015-2019. The result of this study profitability affects the capital structure of property companies, while in building construction companies profitability has no effect on the capital structure. Liquidity in property companies affects the capital structure. This is the same as the result of building construction companies where liquidity affects the capital structure. In property companies the size of the company has an influence on the capital structure, as well as building construction companies that the variable size of the company affects the capital structure. Sales growth has an influence on the capital structure in property companies, while building construction companies sales growth has no effect on the capital structure. The structure of the property company's assets affects the capital structure. The same indicates that the asset structure of building construction companies affects the capital structure. The difference in the influence of the capital structure of property companies is influenced by profitability, liquidity, company size, sales growth, and asset structure. For the capital structure of building construction is influenced by liquidity, company size, and asset structure. As for variable profitability and sales growth in building construction companies has no effect on the capital structure.
\end{abstract}

Keywords: profitability, liquidity, company size, sales growth, asset structure, capital structure

\begin{abstract}
ABSTRAK
Struktur modal merupakan perbandingan antara modal sendiri dengan modal asing yang dimiliki oleh masing-masing perusahaan. Modal sendiri dapat dibagi menjadi laba ditahan dan kepemilikan perusahaan. Sedangkan modal asing adalah hutang jangka pendek atau hutang jangka panjang. Baik buruknya perusahaan dapat ditentukan melalui struktur permodalan. Melalui struktur permodalan, perusahaan dapat mengalokasikan dana yang dimiliki untuk kegiatan usaha yang sesuai serta bermanfaat bagi kelangsungan perusahaan. Secara umum faktor-faktor yang mempengaruhi struktur modal perusahaan antara lain profitabilitas, likuiditas, ukuran perusahaan, pertumbuhan penjualan, dan struktur aset. Penelitian ini bertujuan untuk mengetahui perbedaan pengaruh struktur modal pada perusahaan properti dan konstruksi bangunan. Penelitian ini menggunakan perusahaan properti dan konstruksi bangunan yang terdaftar di Bursa Efek Indonesia tahun 2015-2019. Hasil penelitian ini profitabilitas berpengaruh terhadap struktur modal perusahaan properti, sedangkan pada perusahaan konstruksi bangunan profitabilitas tidak berpengaruh terhadap struktur modal. Likuiditas pada perusahaan properti mempengaruhi struktur permodalan. Hal ini sama
\end{abstract}

\section{JIAKES}

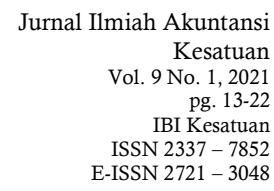


Companies'

Capital Structure

and Pecking Order

14

dengan hasil perusahaan konstruksi bangunan dimana likuiditas mempengaruhi struktur permodalan. Pada perusahaan property ukuran perusahaan memiliki pengaruh terhadap struktur modal, demikian juga halnya dengan perusahaan konstruksi bangunan yang variabel ukuran perusahaan berpengaruh terhadap struktur modal. Pertumbuhan penjualan berpengaruh terhadap struktur modal pada perusahaan properti, sedangkan pertumbuhan penjualan pada perusahaan konstruksi bangunan tidak berpengaruh terhadap struktur modal. Struktur aset perusahaan properti mempengaruhi struktur permodalan. Hal yang sama menunjukkan bahwa struktur aset perusahaan konstruksi bangunan berpengaruh terhadap struktur permodalan. Perbedaan pengaruh struktur modal pada perusahaan properti dipengaruhi oleh profitabilitas, likuiditas, ukuran perusahaan, pertumbuhan penjualan, dan struktur aset. Untuk struktur modal pada konstruksi gedung dipengaruhi oleh likuiditas, ukuran perusahaan, dan struktur aset. Sedangkan untuk variabel profitabilitas dan pertumbuhan penjualan pada perusahaan konstruksi bangunan tidak berpengaruh terhadap struktur modal.

Kata Kunci: profitabilitas, likuiditas, ukuran perusahaan, pertumbuhan penjualan, struktur aset, struktur modal

\section{PENDAHULUAN}

Perkembangan bisnis di Indonesia telah berkembang pesat, dengan kondisi tersebut perusahaan harus lebih kompetitif dalam bersaing untuk mencapai tujuan perusahaan. Tujuan dari suatu perusahaan adalah untuk meningkatkan kemakmuran para pemegang saham dan meraih keuntungan yang maksimal. Keuntungan yang diperoleh suatu perusahaan dapat digunakan untuk mengembangkan usaha agar dapat bersaing dengan perusahaan lain. Dengan begitu perusahaan dapat mengantisipasi persaingan tersebut. Upaya untuk mengantisipasi persaingan ini merupakan permasalahan yang dihadapi perusahaan. Karena setiap perusahaan membutuhkan dana internal maupun eksternal untuk memenuhi kebutuhan dana dan mengembangkan usaha.

Chandrarin \& Cahyaningsih (2018) menjelaskan bahwa struktur modal menunjukkan sebuah proporsi sumber pembiayaan perusahaan antara modal dengan hutang. Struktur modal adalah perbandingan modal sendiri dengan modal asing yang dimiliki oleh setiap perusahaan. Modal sendiri dapat dibagi menjadi laba ditahan dan kepemilikan perusahaan. Sedangkan, modal asing yaitu hutang jangka pendek atau hutang jangka panjang. Menurut Brigham \& Houston (2011) menjelaskan bahwa untuk mengembangkan usaha perusahaan membutuhkan modal tambahan yang berupa hutang maupun ekuitas. Kondisi baik maupun buruk perusahaan dapat ditentukan melalui struktur modal. Dengan melalui struktur modal, perusahaan dapat mengalokasikan dana yang dimiliki untuk kegiatan bisnis yang sesuai serta berguna bagi kelangsungan perusahaan. Brigham \& Houston (2011) berpendapat bahwa faktor-faktor yang mempengaruhi struktur modal yaitu stabilitas penjualan, struktur aktiva, operating leverage, tingkat pertumbuhan, profitabilitas, pajak, pengendalian, sikap manajemen, sikap pemberi pinjaman dan agen pemberi peringkat, kondisi pasar, kondisi internal perusahaan, dan fleksibilitas keuangan. Secara umum, faktor yang mempengaruhi struktur modal perusahaan antara lain profitabilitas, likuiditas, ukuran perusahaan, pertumbuhan penjualan, dan struktur aset.

Profitabilitas merupakan kemampuan perusahaan dalam menghasilkan profit. Perusahaan yang memiliki laba lebih banyak, sehingga perusahaan akan cenderung memilih dana internal atau modal sendiri. Likuiditas adalah kesanggupan perusahaan dalam memenuhi kewajiban jangka pendek. Perusahaan yang memiliki likuiditas tinggi tidak akan menggunakan dana eksternal untuk membiayai kegiatan usaha, karena perusahaan akan memilih untuk menggunakan dana internal. Ukuran perusahaan adalah besar dan kecilnya aset yang dimiliki perusahaan. Perusahaan yang memiliki dana lebih, maka perusahaan akan lebih mudah dalam memperoleh pinjaman. Pertumbuhan penjualan adalah perubahan penjualan dari tahun ke tahun. Perusahaan 
yang memiliki pertumbuhan penjuala yang tinggi, sehingga perusahaan akan menuntut produksi yang tinggi juga. apabila sumber dana perusahaan tidak dapat memenuhi kebutuhan usahanya, maka perusahaan akan menggunakan hutang untuk membiayai produksi. Struktur aset adalah perbandingan antara aset tetap dengan total aset yang dapat menunjukkan sebarapa besar alokasi dana untuk setiap aset. Perusahaan yang memiliki struktur aset besar, maka perusahaan menggunakan hutang lebih kecil.

Penelitian ini dilakukan pada perusahaan property karena berdasarkan observasi awal perusahaan terdapat ketidaksesuaian antara observasi dengan teori yang digunakan. Dengan adanya perbedaan hasil tersebut sehingga terjadi gab riset dan dapat dilakukan kembali penelitian. Selain itu, Penulis memilih perusahaan kontruksi bangunan dalam penelitian ini. Karena perusahaan kontruksi bangunan mengalami perkembangan pada pembangunan negara besar dalam menghadapi Masyarakat Ekonomi Asia (MEA) dan tentu saja melibatkan perusahaan kontruksi bangunan.

Penelitian ini menggunakan teori pecking order. Teori pecking order ditemukan oleh Donaldson pada tahun 1984. Setelah itu, teori tersebut disempurnakan oleh Myers dan Majluf pada tahun yang sama. Teori pecking order menjelaskan bahwa perusahaan yang memiliki profit tinggi mempunyai tingkat hutang yang rendah. Dalam teori ini terdapat urutan pendanaan perusahaan yaitu yang pertama dana yang berasal dari dalam perusahaan (internal) berupa laba ditahan, yang kedua dana eksternal yang berupa hutang, untuk yang terakhir dari penerbitan saham baru.

Struktur permodalan adalah pendanaan tetap yang meliputi hutang jangka panjang, saham preferen, dan modal pemegang saham (Weston \& Copeland, 1999). Menurut Munawir (2007) menyatakan bahwa modal merupakan hak yang dimiliki oleh pemilik perusahaan dalam modal saham, dimana keuntungannya atau laba ditahan yang dimiliki perusahaan terhadap seluruh hutangnya. Munawir (2007) menyatakan bahwa profitabilitas merupakan kinerja perusahaan yang bertujuan untuk menghasilkan keuntungan atau laba. Profitabilitas adalah daya perusahaan untuk menghasilakn laba dalam periode tertentu. Menurut Husaeni (2018) profitabilitas yaitu membandingkan laba bersih dengan total aset yang dimiliki perusahaan. Menurut Horne \& Wachowicz (2012) menyatakan bahwa likuiditas adalah suatu rasio yang diperlukan untuk mengukur perusahaan dalam memenuhi kewajiban jangka pendek. Dalam rasio ini membandingkan kewajiban jangka pendek dengan sumber daya jangka pendek (aktiva lancar) yang dimiliki perusahaan. sumber daya jangka pendek ini digunakan untuk memenuhi kewajiban jangka pendek.

Riyanto (2001) berpendapat bahwa salah satu variabel yang mempengaruhi struktur modal adalah ukuran perusahaan. Ukuran perusahaan adalah variabel yang dapat menggambarkan seberapa besar dan kecil perusahaan berdasarka total aktiva, log aset, dan lain-lain. Menurut Harahap (2016) pertumbuhan penjualan merupakan selisih antara jumlah penjualan tahun sekarang dengan tahun sebelumnya dan dibandingkan dengan penjualan tahun sebelumnya. Pertumbuhan penjualan adalah mencerminkan peningkatan penjualan dari tahun ke tahun. Struktur aset adalah rasio untuk mencerminkan proporsi aktiva tetap dengan total aktiva yang dimiliki perusahaan (Puhirta \& Yudiantoro, 2018). Struktur aset merupakan perbandingan antara aktiva tetap dengan total aktiva.

\section{Hipotesis}

$\mathrm{H} 1_{\mathrm{a}}$ : Profitabilitas berpengaruh terhadap Struktur Modal pada perusahaan Property yang terdaftar di Bursa Efek Indonesia (BEI) periode 2015-2019.

$\mathrm{H}_{\mathrm{b}}$ : Profitabilitas berpengaruh terhadap Struktur Modal pada perusahaan Kontruksi Bangunan yang terdaftar di Bursa Efek Indonesia (BEI) periode 2015-2019.

$\mathrm{H} 2_{\mathrm{a}}$ : Likuiditas berpengaruh terhadap Struktur Modal pada perusahaan Property yang terdaftar di Bursa Efek Indonesia (BEI) periode 2015-2019.

$\mathrm{H} 2_{\mathrm{b}}$ : Likuiditas berpengaruh terhadap Struktur Modal pada perusahaan Kontruksi Bangunan yang terdaftar di Bursa Efek Indonesia (BEI) periode 2015-2019.

$\mathrm{H}_{\mathrm{a}}$ : Ukuran Perusahaan berpengaruh terhadap Struktur Modal pada perusahaan Property yang terdaftar di Bursa Efek Indonesia (BEI) periode 2015-2019.
Companies'

Capital Structure and Pecking Order 
Companies'

Capital Structure

and Pecking Order

16
$\mathrm{H}_{\mathrm{b}}$ : Ukuran Perusahaan berpengaruh terhadap Struktur Modal pada perusahaan Kontruksi Bangunan yang terdaftar di Bursa Efek Indonesia (BEI) periode 20152019.

$\mathrm{H} 4_{\mathrm{a}}$ : Pertumbuhan Penjualan berpengaruh terhadap Struktur Modal pada perusahaan Property yang terdaftar di Bursa Efek Indonesia (BEI) periode 2015-2019.

$\mathrm{H} 4_{\mathrm{b}}$ : Pertumbuhan Penjualan berpengaruh terhadap Struktur Modal pada perusahaan Kontruksi Bangunan yang terdaftar di Bursa Efek Indonesia (BEI) periode 20152019.

$\mathrm{H} 5_{\mathrm{a}}$ : Struktur Aset berpengaruh terhadap Struktur Modal pada perusahaan Property yang terdaftar di Bursa Efek Indonesia (BEI) periode 2015-2019.

$\mathrm{H} 5_{\mathrm{b}}$ : Struktur Aset berpengaruh terhadap Struktur Modal pada perusahaan Kontruksi Bangunan yang terdaftar di Bursa Efek Indonesia (BEI) periode 2015-2019.

H6 : Terdapat perbedaan pengaruh profitabilitas, likuiditas, ukuran perusahaan, pertumbuhan penjualan, dan struktur aset terhadap struktur modal pada perusahaan Property dan Kontruksi Bangunan yang terdaftar di Bursa Efek Indonesia (BEI) periode 2015-2019.

\section{Model Penelitian Empirik}

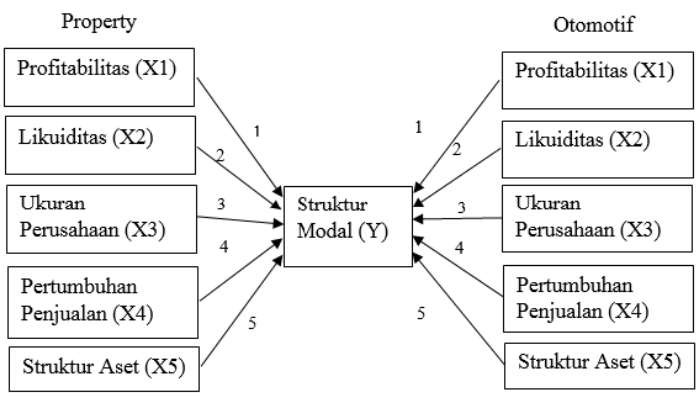

Gambar 1: Model Penelitian Empirik

\section{METODE PENELITIAN}

\section{Populasi dan Sampel}

Populasi adalah dari objek yang hendak diteliti. Populasi dalam penelitian ini merupakan perusahaan property dan kontruksi bangunan yang terdaftar di Bursa Efek Indonesia (BEI) periode 2015-2019. Pemilihan sampel menggunakan metode purposive sampling.

\section{Pengukuran Variabel}

Variabel Dependen

Struktur modal yaitu struktur atau perbandingan antara modal sendiri dengan hutang jangka panjang, maka struktur modal bagian dari komposisi keuangan (Husaeni, 2018). Rumus DER sebagai berikut:

\section{Variabel Independen}

$$
\text { Debt to Equity Ratio }(D E R)=\frac{\text { Total Hutang }}{\text { Total Ekuitas }}
$$

\section{a. Profitabilitas}

Munawir (2007) menyatakan bahwa profitabilitas merupakan kinerja perusahaan yang bertujuan untuk menghasilkan keuntungan atau laba. Profitabilitas adalah daya perusahaan untuk menghasilakn laba dalam periode tertentu. Rumus ROA antara lain:

\section{b. Likuiditas}

$$
R O A=\frac{\text { Laba Setelah Pajak }}{\text { Total Aset }}
$$

Menurut Horne \& Wachowicz (2012) menyatakan bahwa likuiditas adalah suatu rasio yang diperlukan untuk mengukur perusahaan dalam memenuhi kewajiban jangka pendek. Menurut Fahmi (2015) current rasio dirumuskan sebagai berikut: 


\section{c. Ukuran Perusahaan}

$$
\text { Current Ratio }(C R)=\frac{\text { Aktiva Lancar }}{\text { Hutang Jangka Pendek }}
$$

Ukuran perusahaan adalah variabel yang dapat menggambarkan seberapa besar dan kecil perusahaan berdasarka total aktiva, log aset, dan lain-lain. Perumusan log alam (LN) total aset adalah sebagai berikut:

$$
\text { Ukuran Perusahaan }=\text { Ln Total Aset }
$$

d. Pertumbuhan Penjualan

Menurut Harahap (2016) pertumbuhan penjualan merupakan selisih antara jumlah penjualan tahun sekarang dengan tahun sebelumnya dan dibandingkan dengan penjualan tahun sebelumnya. Dalam observasi (Rahmadani et al., 2019) pertumbuhan penjualan dapat dirumuskan di bawah ini:

\section{e. Struktur Aset}

$$
\text { Pertumbuhan Penjualan }=\frac{\text { Penjualan }(t)-\text { Penjualan }(t-1)}{\text { Penjualan }(t-1)}
$$

Menurut Puhirta \& Yudiantoro (2018) struktur aset adalah rasio untuk mencerminkan proporsi aktiva tetap dengan total aktiva yang dimiliki perusahaan. Rumus dari struktur aset sebagai berikut:

\section{Teknik Pengumpulan Data}

$$
\text { Struktur Aset }=\frac{\text { Aktiva Tetap }}{\text { Total Aktiva }}
$$

Jenis penelitian ini menggunakan penelitian kuantitatif. Sumber data yang digunakan dalam penelitian ini adalah data sekunder. Dalam observasi ini, data sekunder didapat dari laporan keuangan tahunan (annual report) perusahaan property dan kontruksi bangunan yang terdaftar di Bursa Efek indonesia (BEI) periode 20152019. Instrumen penelitian ini menggunakan dokumentasi.

\section{Teknik Analisis Data}

Teknik analisis data yang digunakan dalam penelitian ini menggunakan analisis linier berganda dengan aplikasi IBM SPSS 21.

\section{Statistik Deskriptif}

Analisis statistik deskriptif berisi tentang minimal, maximal, mean, sum, standar deviasi, variance, range, dan sebagainya. Selain itu, statistik deskriptif digunakan untuk mengukur distribusi data dengan cara skewness dan kurtosis.

\section{Metode Analisis Regresi Linier Berganda}

Analisis regresi linier adalah analisis untuk mengetahui pengaruh variabel independen terhadap variabel dependen dan untuk meramalkan suatu variabel dependen berdasarkan variabel independen.

Keterangan:

$$
Y=a+b_{1} X_{1}+b_{2} X_{2}+b_{3} X_{3}+b_{4} X_{4}+b_{5} X_{5}+e
$$

$\begin{array}{ll}\mathrm{Y} & : \text { Struktur Modal (DER) } \\ \mathrm{a} & : \text { Konstanta } \\ \mathrm{b}_{1} \mathrm{~b}_{2} \mathrm{~b}_{3} \mathrm{~b}_{4} \mathrm{~b}_{5} & \text { : Koefisien Regresi } \\ \mathrm{X}_{1} & \text { : Profitabilitas (ROA) } \\ \mathrm{X}_{2} & \text { : Likuiditas (CR) } \\ \mathrm{X}_{3} & \text { : Ukuran Perusahaan } \\ \mathrm{X}_{4} & \text { : Pertumbuhan Penjualan } \\ \mathrm{X}_{5} & : \text { Struktur Aset } \\ \mathrm{e} & : \text { error }\end{array}$

\section{HASIL DAN PEMBAHASAN}

Analisis Statistik Deskriptif

Jumlah sampel yang digunakan pada semua variabel adalah 107 sampel. Berdasarkan hasil uji statistik deskriptif dalam penelitian ini menunjukkan bahwa variabel dependen yaitu struktur modal (DER), jumlah sampel (N) adalah 107, nilai 
Companies'

Capital Structure

and Pecking Order

18 minimumnya sebesar 0,066 , nilai maximum 2,197 , nilai mean 0,76418 , dan nilai standar deviasi adalah 0,511478. Variabel independen dalam penelitian ini yaitu profitabilitas (ROA) yang memiliki nilai minimum 0,000 , nilai maximum 0,124 , nilai mean 0,04484 dan nilai standar deviasi 0,033470. Likuiditas (CR) mempunyai nilai minimum 0,618 , nilai maximum 5,766, nilai mean 2,04536 serta nilai standar deviasi 1,153363 . Ukuran perusahaan (SIZE) memiliki nilai minimum 25,892 , nilai maximum 31,628, nilai mean 29,51296, dan nilai standar deviasi 1,324662. Pertumbuhan penjualan (SG) yang mempunyai nilai minimum $-0,912$, nilai maximum 0,593 , nilai mean $-0,06465$ serta nilai standar deviasi 0,358660 . Struktur aset (AST) memiliki nilai minimum 0,000 , nilai maximum 0,176 , nilai mean 0,05002 , dan nilai standar deviasi 0,043929 .

Tabel 1 Hasil Uji Statistik Deskriptif Property

\begin{tabular}{|c|c|c|c|c|c|}
\hline Variables & $\mathrm{N}$ & Minimum & Maximum & n Mean & Std. Deviation \\
\hline DER & 107 & 0,066 & 2,197 & 0,76418 & 0,511478 \\
\hline ROA & 107 & 0,000 & $-0,124$ & 0,04484 & 0,033470 \\
\hline $\mathrm{CR}$ & 107 & 0,618 & 5,766 & 2,04536 & 1,153363 \\
\hline SIZE & 107 & 25,892 & 31,628 & 29,51296 & 1,324662 \\
\hline SG & 107 & $-0,912$ & 0,593 & $-0,06465$ & 0,358660 \\
\hline AST & 107 & 0,000 & 0,176 & 0,05002 & 0,043929 \\
\hline Valid N (listwise) & 107 & & & & \\
\hline
\end{tabular}

Sumber: Data sekunder yang diolah

Tabel 2 Hasil Uji Statistik Deskriptif Kontruksi Bangunan

\begin{tabular}{lcrrrc}
\hline & $\mathrm{N}$ & \multicolumn{1}{c}{ Minimum } & \multicolumn{1}{c}{ Maximum } & Mean & Std. Deviation \\
\hline DER & 35 & 0,689 & 4,343 & 1,88939 & 1,048277 \\
ROA & 35 & 0,008 & 0,247 & 0,5271 & 0,043696 \\
CR & 35 & 1,002 & 2,368 & 1,51372 & 0,314913 \\
SIZE & 35 & 28,322 & 32,454 & 30,01285 & 1,326375 \\
SG & 35 & $-0,357$ & 0,901 & 0,09868 & 0,258185 \\
AST & 35 & 0,033 & 0,178 & 0,09308 & 0,049933 \\
Valid N (listwise) & 35 & & & & \\
\hline
\end{tabular}

Sumber: Data sekunder yang diolah

Berdasarkan tabel 2, jumlah sampel yang digunakan semua variabel yaitu 35 sampel. Variabel dependennya merupakan struktur modal (DER) yang mempunyai nilai minimum 0,689, nilai maximum 4,343, nilai mean 1,88939 dan standar deviasi 1,048277. Variabel independennya yaitu profitabilitas (ROA), nilai minimum 0,008 , nilai maximum 0,247 , nilai mean 0,05271 , serta nilai standar deviasinya 0,43696 . Likuiditas (CR) memiliki nilai minimum 1,002, nilai maximum 2,368, nilai mean 1,51372, dan standar deviasi 0,314913. Ukuran perusahaan (SIZE) mempunyai nilai minimum 28,322, nilai maximum 32,454, nilai mean 30,01285, serta nilai standar deviasi 1,326375 . Pertumbuhan penjualan (SG) memiliki nilai minimum $-0,357$, nilai maximum 0,901, nilai mean 0,09868, dan standar deviasi 0,258185. Struktur aset (AST) nilai minimumnya 0,033 , nilai maximum 0,178 , nilai mean 0,09308 , dan standar deviasi 0,049933 .

\section{Uji Asumsi Klasik}

Penelitian ini, untuk uji normalitas menggunakan uji One Sample KolmogorovSmirnov. Pada perusahaan property data terdistribusi normal atau uji normalitas telah terpenuhi. Hasil ini sama dengan perusahaan kontruksi bangunan yang juga terdistribusi normal. Dalam penelitian ini, untuk mengetahui uji multikolinieritas dengan melihat melalui nilai tolerance dan inflation factor (VIF). Jika nilai VIF kurang dari 10 dan toleransi lebih besar dari 0,1 , ini menyatakan bahwa tidak ada multikolinieritas (Ghozali, 2013). Hasilnya tidak terjadi multikolinieritas baik property maupun kontruksi bangunan. Dalam observasi ini, menggunakan uji Durbin Watson. Hasilnya kedua perusahaan tidak terjadi autokorelasi. Dalam penelitian ini uji 
heteroskedastisitas menggunakan teknik uji koefisien korelasi Spearman rho. Property dan kontruksi bangunan tidak terjadi heteroskedastisitas.

\section{Analisis regresi Linier Berganda}

Pada property yang mempengaruhi struktur modal yaitu profitabilitas, likuiditas, ukuran perusahaan, pertumbuhan penjualan, dan struktur aset. Sedangkan kontruksi bangunan yaitu likuiditas, ukuran perusahaan, dan struktur aset. Maka modelnya:

$$
\begin{aligned}
& \mathrm{DER}_{\text {Property }}=-1,347-2,644 \mathrm{ROA}-0,089 \mathrm{CR}+0,076 \mathrm{SIZE}+0,593 \mathrm{SG}+4,231 \mathrm{AST}+ \\
& \mathrm{e} \\
& \text { DER Kontruksi Bangunan }=-6,892+1,115 \text { ROA }-1,294 \text { CR + 0,382 SIZE - 0,393 SG - } \\
& 7,867 \mathrm{AST}+\mathrm{e}
\end{aligned}
$$

\section{Uji Kelayakan Model (Uji F)}

Pada perusahaan property $\mathrm{F}$ hitung $>\mathrm{F}$ tabel dan signifikansi $<0,05(0,000<$ $0,05)$, maka variabel profitabilitas, likuiditas, ukuran perusahaan, pertumbuhan penjualan dan struktur aset secara bersama-sama berpengaruh terhadap struktur modal. Pada kontruksi bangunan $F$ hitung $>$ F tabel dan signifikansi $<0,05(0,000$ $<0,05)$, sehingga variabel profitabilitas, likuiditas, ukuran perusahaan, pertumbuhan penjualan, dan struktur aset secara bersama-sama berpengaruh terhadap struktur modal.

Tabel 3 Hasil Uji Kelayakan Model (Uji F)

\begin{tabular}{lrccl}
\hline F Hitung & F Tabel & Sig. & Syarat & Keterangan \\
\hline Property & & & & \\
20,766 & $>2,304$ & 0,000 & $<0,05$ & Model Layak \\
Kontruksi Bangunan & & & \\
20,767 & $>2,545$ & 0,000 & $<0,05$ & Model Layak \\
\hline
\end{tabular}

Sumber: Data sekunder yang diolah

Uji Hipotesis

Tabel 4 Hasil Uji Hipotesis (Uji t)

\begin{tabular}{lccccl}
\hline Hipotesis & t Hitung & t Tabel & Sig. & Syarat & Hasil \\
\hline property & & & & & \\
$\mathrm{H} 1_{\mathrm{a}}$ & $-2,367$ & $>-1,983$ & 0,020 & $<0,05$ & Diterima \\
$\mathrm{H} \mathrm{a}_{\mathrm{a}}$ & $-2,754$ & $>-1,983$ & 0,007 & $<0,05$ & Diterima \\
$\mathrm{H} \mathrm{a}_{\mathrm{a}}$ & 2,414 & $>1,983$ & 0,018 & $<0,05$ & Diterima \\
$\mathrm{H} 4_{\mathrm{a}}$ & 5,488 & $>1,983$ & 0,000 & $<0,05$ & Diterima \\
$\mathrm{H} 5_{\mathrm{a}}$ & 4,721 & $>1,983$ & 0,000 & $<0,05$ & Diterima \\
$\mathrm{K}{ }_{\mathrm{n}}$ truksi Bangunan & & & & \\
$\mathrm{H} \mathrm{b}_{\mathrm{b}}$ & 0,483 & $>2,045$ & 0,635 & $<0,05$ & Ditolak \\
$\mathrm{H} \mathrm{b}_{\mathrm{b}}$ & $-3,463$ & $>-2,045$ & 0,002 & $<0,05$ & Diterima \\
$\mathrm{H} \mathrm{b}_{\mathrm{b}}$ & 4,211 & $>2,045$ & 0,000 & $<0,05$ & Diterima \\
$\mathrm{H} 4_{\mathrm{b}}$ & $-1,004$ & $>-2,045$ & 0,323 & $<0,05$ & Ditolak \\
$\mathrm{H} 5_{\mathrm{b}}$ & $-3,983$ & $>-2,045$ & 0,000 & $<0,05$ & Diterima \\
\hline
\end{tabular}

Sumber: Data sekunder yang diolah

Uji Koefisien Determinasi $\left(R^{2}\right)$

Perusahaan property nilai R-squared sebesar 0,383 artinya kelima variabel tersebut memberikan kontribusi sebesar 38,3\% terhadap struktur modal, sedangkan variabel sisanya dipengaruhi oleh variabel lain yang tidak termasuk dalam model ini. Sedangkan kontruksi bangunan nilai R-squared sebesar 0,825 artinya kontribusi kelima variabel tersebut terhadap struktur modal sebesar $82,5 \%$, sedangkan variabel sisanya dipengaruhi oleh variabel lain yang tidak termasuk dalam model ini.

Pengaruh Profitabilitas terhadap Struktur Modal

Berdasarkan pengujian data dan asumsi, dapat diketahui bahwa profitabilitas berpengaruh terhadap struktur modal pada perusahaan property. Hal ini sejalan dengan penelitian Chandrarin \& Cahyaningsih (2018). Maka semakin tinggi profitabilitas perusahaan maka semakin rendah struktur modalnya. Hasil pengujian data dan hipotesis untuk perusahaan kontruksi bangunan dapat diketahui bahwa 
Companies'

Capital Structure

and Pecking Order

20

profitabilitas tidak berpengaruh terhadap struktur modal. Hal ini sejalan dengan penelitian Septiani \& Suaryana (2018). Perusahaan telah menetapkan struktur permodalan berdasarkan besarnya keuntungan, pengorbanan dari penggunaan dukungan hutang Operasi perusahaan.

\section{Pengaruh Likuiditas terhadap Struktur Modal}

Berdasarkan hasil pengujian data dan asumsi dapat diketahui bahwa likuiditas berpengaruh terhadap struktur modal perusahaan property. Sedangkan hasil ini sama dengan perusahaan kontruksi bangunan dimana likuiditas berpengaruh terhadap struktur modal. Hal ini sejalan dengan penelitian Pertiwi \& Darmayanti (2018). Seiring dengan peningkatan hutang jangka panjang, hal itu akan mengurangi penggunaan hutang jangka panjang Semakin tinggi tingkat likuiditas perusahaan maka perusahaan akan mengurangi penggunaan Hutang jangka panjang, menghasilkan likuiditas dan Struktur Modal.

\section{Pengaruh Ukuran Perusahaan terhadap Struktur Modal}

Berdasarkan hasil pengujian data dan asumsi dapat diketahui bahwa ukuran perusahaan berpengaruh terhadap struktur modal perusahaan property dan kontruksi bangunan. Hal ini sesuai dengan penelitian Septiani \& Suaryana (2018). Semakin tinggi dan tinggi Semakin besar perusahaan, semakin baik struktur permodalan perusahaan.

\section{Pengaruh Pertumbuhan Penjualan terhadap Struktur Modal}

Berdasarkan output pengujian data dan hipotesis diketahui bahwa pertumbuhan penjualan berpengaruh terhadap struktur modal pada perusahaan property. Hasil ini sejalan dengan observasi Chandrarin \& Cahyaningsih (2018). Semakin tinggi penjualan, maka semakin tinggi pula keuntungan yang akan didapat perusahaan. Hasil pengujian data dan hipotesis pada perusahaan kontruksi bangunan menunjukkan pertumbuhan penjualan tidak berpengaruh terhadap struktur modal. Hal ini sesuai dengan penelitian Husaeni (2018). Dalam hal ini investor tidak hanya harus mempertimbangkan ukuran perusahaan, tetapi juga mempertimbangkan prospek perusahaan, analisa bisnis dan faktor lain untuk membeli saham atau berinvestasi

\section{Pengaruh Struktur Aset terhadap Struktur Modal}

Menurut output dari pengujian data dan hipotesis menunjukkan bahwa struktur aset berpengaruh terhadap struktur modal pada perusahaan property. Sementara itu, hasil tersebut sama dengan perusahaan kontruksi bangunan dimana struktur aset juga berpengaruh terhadap struktur modal. Hasil penelitian ini sejalan dengan observasi Cipto et al. (2019). Artinya jika semakin besar aktiva tetap perusahaan maka semakin besar pula peluang perusahaan untuk menggunakan hutang, sehingga struktur modal perusahaan juga akan semakin besar.

Perbedaan Pengaruh Profitabilitas, Likuidtas, Ukuran Perusahaan, Pertumbuhan Penjualan, dan Struktur Aset terhadap Struktur Modal pada Perusahaan Property dan Kontruksi Bangunan

Berdasarkan dari hasil pengujian data dan hipotesis untuk variabel profitabilitas pada perusahaan property berpengaruh terhadap struktur modal, sedangkan pada kontruksi bangunan variabel profitabilitas tidak berpengaruh terhadap struktur modal. Likuiditas pada property dan kontruksi bangunan berpengaruh terhadap struktur modal. Pada perusahaan property dan kontruksi bangunan, ukuran perusahaan sama-sama berpengaruh terhadap struktur modal. Hasil uji pada perusahaan property pertumbuhan penjualan berpengaruh terhadap struktur modal, sedangkan di kontruksi bangunan pertumbuhan penjualan tidak berpengaruh terhadap struktur modal. Struktur aset berpengaruh terhadap struktur modal pada perusahaan property dan kontruksi bangunan. Hasil ini sejalan dengan penelitian Awaluddin et al. (2019).

\section{PENUTUP}

Berdasarkan pembahasan hasil penelitian diatas dapat disimpulkan: 
1. Hasil penelitian ini profitabilitas berpengaruh terhadap struktur modal pada perusahaan property, sedangkan pada perusahaan kontruksi bangunan profitabilitas tidak berpengaruh terhadap struktur modal.

2. Likuiditas pada perusahaan property dan kontruksi bangunan berpengaruh terhadap struktur modal.

3. Pada perusahaan property ukuran perusahaan memiliki pengaruh terhadap struktur modal, begitu pun perusahaan kontruksi bangunan.

4. Pertumbuhan penjualan memiliki pengaruh terhadap struktur modal pada perusahaan property, sedangkan perusahaan kontruksi bangunan pertumbuhan penjualan tidak berpengaruh terhadap struktur modal.

5. Struktur aset perusahaan property serta kontruksi bangunan mempengaruhi struktur modal.

6. Pada perbedaan pengaruh struktur modal perusahaan property dipengaruhi oleh profitabilitas, likuiditas, ukuran perusahan, pertumbuhan penjualan, dan struktur aset. Untuk struktur modal kontruksi bangunan dipengaruhi oleh likuiditas, ukuran perusahaan, dan struktur aset. Sedangkan untuk variabel profitabilitas dan pertumbuhan penjualan pada perusahaan kontruksi bangunan tidak berpengaruh terhadap struktur modal.

\section{DAFTAR PUSTAKA}

Awaluddin, M., Amalia, K., Sylvana, A., \& Wardhani, R. S. (2019). Perbandingan Pengaruh Return On Asset, Pertumbuhan Aset, Pertumbuhan Penjualan Dan Managerial Ownership Terhadap Struktur Modal Perusahaan Multinasional Dan Domestik Di BEI. Jurnal Minds: Manajamen Ide Dan Inspirasi, 6(1), 113-128. https://doi.org/10.24252/minds.v6i1.7965

Brigham, F., \& Houston, J. (2011). Dasar-Dasar Manajemen Keuangan (Edisi 11 ed). Salemba Empat.

Chandrarin, G., \& Cahyaningsih, D. S. (2018). Identifikasi Struktur Modal Melalui Profitabilitas, Pertumbuhan Penjualan dan Ukuran Perusahaan. AFRE (Accounting and Financial Review), 1(1), 36-45. https://doi.org/10.26905/afr.v1i1.2246

Cipto, P. K. A., Choeruding, A., \& Suryanti, Y. (2019). The Factors That Affecting Structure Capital In Manufacturing Companies: The Study In Indonesia Of 20122014. International Journal of Information, Business and Management, 11(3), 227-234.

Effendy, M., \& Pamungkas, A. D. (2018). Analisis Beta Saham Harian Terhadap Imbal Saham Harian Sebuah Studi Kasus Saham-Saham LQ45 pada Periode FebruariJuli 2015. Jurnal Ilmiah Manajemen Kesatuan, 6(1), 33-42.

Fahmi, I. (2015). Pengantar Manajemen Keuangan Teori dan Soal Jawab. Alfabeta.

Ghozali, I. (2013). Aplikasi Analisis Multivriate dan Program IBM SPSS 21 (Edisi 7 ed.). Badan Penerbit UNDIP.

Harahap, S. . (2016). Analisis Kritis Manajemen Keuangan. PT Raja Grafindo Persada.

Horne, J. C. V., \& Wachowicz, J. M. (2012). Prinsip-Prinsip Manajemen Keuangan. Salemba Empat.

Husaeni, U. A. (2018). Determinants Of Capital Structure In Companies Listed In The Jakarta Islamic Index. International Journal of Economics, Management and Accounting, $26(2), 443-456$.

Laksono, M. A., \& Hidayat, L. (2018). Analisis Manajemen Aset. Jurnal Ilmiah Manajemen Kesatuan, 6(3), 109-116.

Munawir, S. (2007). Analisis Laporan Keuangan. Yogyakarta.

Pertiwi, N. K. N. I., \& Darmayanti, N. P. A. (2018). Pengaruh Profitabilitas, Likuiditas, Struktur Aktiva Dan Kebijakan Dividen Terhadap Struktur Modal Perusahaan Manufaktur Di Bei. E-Jurnal Manajemen Universitas Udayana, 7(6), 3115-3143. https://doi.org/10.24843/EJMUNUD.2018.v07.i06.p10

Puhirta, Y. A., \& Yudiantoro, A. (2018). Pengaruh Ukuran Perusahaan, Profitabilitas, Likuiditas, Dan Struktur Aset Terhadap Struktur Modal (Studi Empiris Pada 
Companies'

Capital Structure

and Pecking Order

22
Perusahaan real estate Dan Properti Yang Terdaftar Di BEI Tahun 2012-2014). Kajian Akuntansi, 13(2), 144-155.

Rahmadani, Ananto, R. P., \& Andriani, W. (2019). Pengaruh Profitabilitas, Likuiditas, Ukuran Perusahaan, Pertumbuhan Penjualan dan Dividend Payout Ratio Terhadap Struktur Modal (Studi Pada Perusahaan Property Dan real estate YangTerdaftar Di BEI Tahun 2013-2017). Akuntansi Dan Manajemen, 14(1), 82103.

Riyanto. (2001). Dasar-Dasar Pembelanjaan Perusahaan. BPFE.

Septiani, N. P. N., \& Suaryana, I. G. N. A. (2018). Pengaruh Profitabilitas, Ukuran Perusahaan, Struktur Aset, Risiko Bisnis dan Likuiditas pada Struktur Modal. EJurnal Akuntansi Universitas Udayana, 22(3), 1682-1710. https://doi.org/10.24843/eja.2018.v22.i03.p02

Setiawan, H., \& Lisias, V. (2009). Evaluasi atas harga pokok produk sampingan dalam kaitannya dengan perhitungan laba perusahaan (study kasus pada CV. Morinda House Bogor). Jurnal Ilmiah Ranggagading (JIR), 9(2), 85-91.

Weston, J. F., \& Copeland, T. E. (1999). Manajemen Keuangan. Binarupa Aksara. 